\title{
DOES NITROGEN APPLICATION TIMING AND SOURCES INFLUENCE BARLEY GRAIN YIELD?
}

\author{
Marcos Renan Besen ${ }^{1}$, Ricardo Henrique Ribeiro ${ }^{2}$, Felipe Bratti ${ }^{2}$, \\ Jorge Luiz Locatelli ${ }^{3}$, Jonatas Thiago Piva ${ }^{4}$ \\ SAP 24011 Received: 08/02/2020 Accepted: 09/06/2020 \\ Sci. Agrar. Parana., Marechal Cândido Rondon, v. 19, n. 3, jul./sep., p. 264-269, 2020
}

\begin{abstract}
The suitable management of nitrogen $(\mathrm{N})$ fertilization can increase barley grain yield, since it is the nutrient required in greater quantity. In this sense, the source and timing of nitrogen application are relevant factors. The objective was to evaluate the effects of $\mathrm{N}$ sources and splitting on the performance of barley. The experiment was carried out under a clayey Cambisol (550 $\left.\mathrm{g} \mathrm{kg}^{-1}\right)$, in Curitibanos, Santa Catarina. Factorial randomized blocks were used: three mineral sources of N: urea $(45 \% \mathrm{~N})$; urea with urease inhibitor-NBPT $(45 \%$ of $\mathrm{N})$ and nitrate $(30 \%$ of $\mathrm{N})$, associated with two nitrogen splitting fertilization: i) split of the rate of $\mathrm{N}$ in two seasons: beginning of tillering and full tillering and ii) single application at full tillering. $100 \mathrm{~kg} \mathrm{ha}^{-1}$ of $\mathrm{N}$ were applied. There was no interaction between the factors and there was no effect of treatments for plant height, ear length, grains per ear, ears per $\mathrm{m}^{2}$ and mass of a thousand grains. Yield was influenced by the $\mathrm{N}$ source, where nitrate exceeded the yield from amidic sources by $16 \%$. The splitting of $\mathrm{N}$ in two times did not present advantages over the single application. Urea with NBPT was not viable in relation to readily soluble forms of N, with the highest yield obtained with a nitric source.
\end{abstract}

Keywords: enhanced-efficiency fertilizers, Hordeum vulgare L., NBPT, nitrate.

\section{ÉPOCAS DE APLICAÇÃO E FONTES DE NITROGÊNIO INTERFEREM NA PRODUTIVIDADE DA CEVADA?}

\begin{abstract}
RESUMO - O manejo adequado da adubação nitrogenada pode propiciar maior rendimento de grãos de cevada, visto que é o nutriente requerido em maior quantidade. Nesse sentido, a fonte e a época de aplicação de nitrogênio (N) são fatores relevantes. Diante do exposto, objetivou-se com o presente trabalho avaliar o efeito de fontes de $\mathrm{N}$ e o parcelamento das doses no desempenho da cevada. O experimento foi conduzido sob um Cambissolo Háplico Argiloso (550 $\mathrm{g} \mathrm{kg}^{-1}$ ), no município de Curitibanos, Santa Catarina. O delineamento foi de blocos ao acaso em esquema fatorial: sendo três fontes minerais de N: ureia ( $45 \%$ de $\mathrm{N})$; ureia com inibidor de urease-NBPT (45\% de N) e nitrato (30\% de N), associados à duas épocas de adubação nitrogenada: i) parcelamento da dose de $\mathrm{N}$ em duas épocas: início do perfilhamento e perfilhamento pleno e ii) aplicação integral da dose em perfilhamento pleno. Foram aplicados $100 \mathrm{~kg} \mathrm{ha}^{-1}$ de N. Não houve interação entre os fatores e não houve efeito dos tratamentos para altura de planta, comprimento de espiga, grãos por espiga, espigas por $\mathrm{m}^{2}$ e massa de mil grãos. A produtividade foi influenciada pela fonte de $\mathrm{N}$, onde o nitrato superou em $16 \%$ o rendimento oriundo das fontes amídicas. A aplicação de $\mathrm{N}$ parcelada em duas etapas não apresentou vantagens em relação a aplicação única. A ureia com NBPT não se mostrou viável em relação as formas de $\mathrm{N}$ prontamente solúveis, sendo o maior rendimento obtido com a fonte nítrica.
\end{abstract}

Palavras-chave: fertilizantes de eficiência aprimorada, Hordeum vulgare L., NBPT, nitrato.

\section{INTRODUCTION}

Barley (Hordeum vulgare L.) is one of the few options for grain crops during the cold season for southern Brazil. However, its cropping can be an important income source for the farmer, in addition to composing crop rotation systems in succession to maize, soybeans and beans. In the 2019 crop-season, 118,800 ha of barley were cultivated in Brazil, with an estimated production of 429,100 tons, obtained in its entirety in the southern region of the country, whose mean yield was $3,612 \mathrm{~kg} \mathrm{ha}^{-1}$ (CONAB , 2020). Part of the barley production is intended to be malting, and another part directed to feed production.
For the next few years, incentives are expected to grow barley and other winter cereals in order to reduce dependence on maize in the manufacture of feed for pigs and poultry (SEAPDR, 2019). Thus, fertility management practices that favor crop yield and grain quality (WAMSER and MUNDSTOCK, 2007) should be sought, aiming at greater efficiency of fertilizer use (MUURINEN et al., 2006).

With regard to the nutritional aspect, nitrogen $(\mathrm{N})$ is the nutrient required in greater quantity by barley (MUURINEN et al., 2006). It is estimated that, for each ton of grain produced, nearly $23.1 \mathrm{~kg}$ of $\mathrm{N}$ are extracted

\footnotetext{
${ }^{1}$ Universidade Estadual de Maringá (UEM), Maringá, Paraná, Brazil. E-mail: marcos.besen @ hotmail.com. *Corresponding Author.

${ }^{2}$ Universidade Federal do Paraná (UFPR), Curitiba, Paraná, Brazil.

${ }^{3}$ Escola Superior de Agricultura Luiz de Queiroz (ESALQ/USP), Piracicaba, São Paulo, Brazil.

${ }^{4}$ Universidade Tecnológica Federal do Paraná (UTFPR), Santa Helena, Paraná, Brazil.
} 
and that, of this amount, $15.6 \mathrm{~kg}$ are exported (SBCS/NEPAR, 2019). Nitrogen plays vital functions for the plant, with structural function in amino acids and proteins, glycol and lipoproteins, vitamins, in addition to acting in the constitution of all the enzymes and activating countless of them (MALAVOLTA et al., 1997). Efficient fertilization with $\mathrm{N}$ is crucial for economic barley production. Excess of $\mathrm{N}$ increases susceptibility to diseases, pests and lodging, which reduces yield, in addition to increasing the production cost and the likelihood for contaminating the water table (ALLEY et al., 2019). However, $\mathrm{N}$ deficiency results in low yields and reduced profits compared to proper fertilization.

Although urea is a widely used $\mathrm{N}$ source, the use of enhanced efficiency fertilizers (EEFs), which aim to reduce $\mathrm{N}$ losses, has grown substantially in recent years. $\mathrm{N}$-butyl tiophosphoric triamide (NBPT) is the most used urease inhibitor for reducing urea hydrolysis, mitigating $\mathrm{N}$ losses (FORRESTAL et al., 2016). However, Ribeiro et al. (2020) verified that the EEFs, including NBPT applied to barley, were not effective in reducing $\mathrm{N}-\mathrm{NH}_{3}$ compared to conventional urea. There are still few studies evaluating the viability of $\mathrm{N}$ sources, combined with times of application in barley farming in southern Brazil, and it is necessary to understand whether EEFs are advantageous in relation to the readily soluble $\mathrm{N}$ sources, especially in the cropping of winter cereals, under strict winter conditions.

In addition, the timing of nitrogen fertilization is fundamental to achieve higher yields and increase the $\mathrm{N}$ use efficiency (ALLEY et al., 2019). According to
Wamser and Mundstock (2007), the period of greatest response to $\mathrm{N}$ fertilization is between the emission of the third and ninth leaf of the main stem. In this period, the beginning and end of tillering are considered the most critical stages for the application of $\mathrm{N}$, due to the higher requirement of $\mathrm{N}$ for the formation of yield components, number of stems per area, and number of grains per ear.

In this sense, the hypothesis of this work is that using the urease inhibitor NBPT can increase barley yield in relation to readily soluble $\mathrm{N}$ forms and that its use, due to the slower release of $\mathrm{N}$, is equivalent to a splitting use of conventional urea or nitrate. The objective was to evaluate the effect of $\mathrm{N}$ sources and its application timing as topdressing in barley yield and yield components in subtropical climate conditions.

\section{MATERIALS AND METHODS}

The experiment was conducted at the Experimental Agricultural Farm of the Federal University of Santa Catarina (Universidade Federal de Santa Catarina, UFSC), Curitibanos Campus (27²6’26.55” S, $\left.50^{\circ} 30^{\prime} 14.41^{\prime} \mathrm{W}\right)$, located at an altitude of $1,050 \mathrm{~m}$. The soil of the area is a typical HAPLIC CAMBISOL with a clayey texture (550 $\mathrm{g} \mathrm{kg}^{-1}$ clay) (SANTOS et al., 2013) and the climate, according to the Köppen's, is of the $C f b$ type (ALVARES et al., 2013). The mean annual rainfall and temperature values are $1,500 \mathrm{~mm}$ and $15^{\circ} \mathrm{C}$, respectively. Data on rainfall and on the mean air temperature during the experiment are shown in Figure 1.

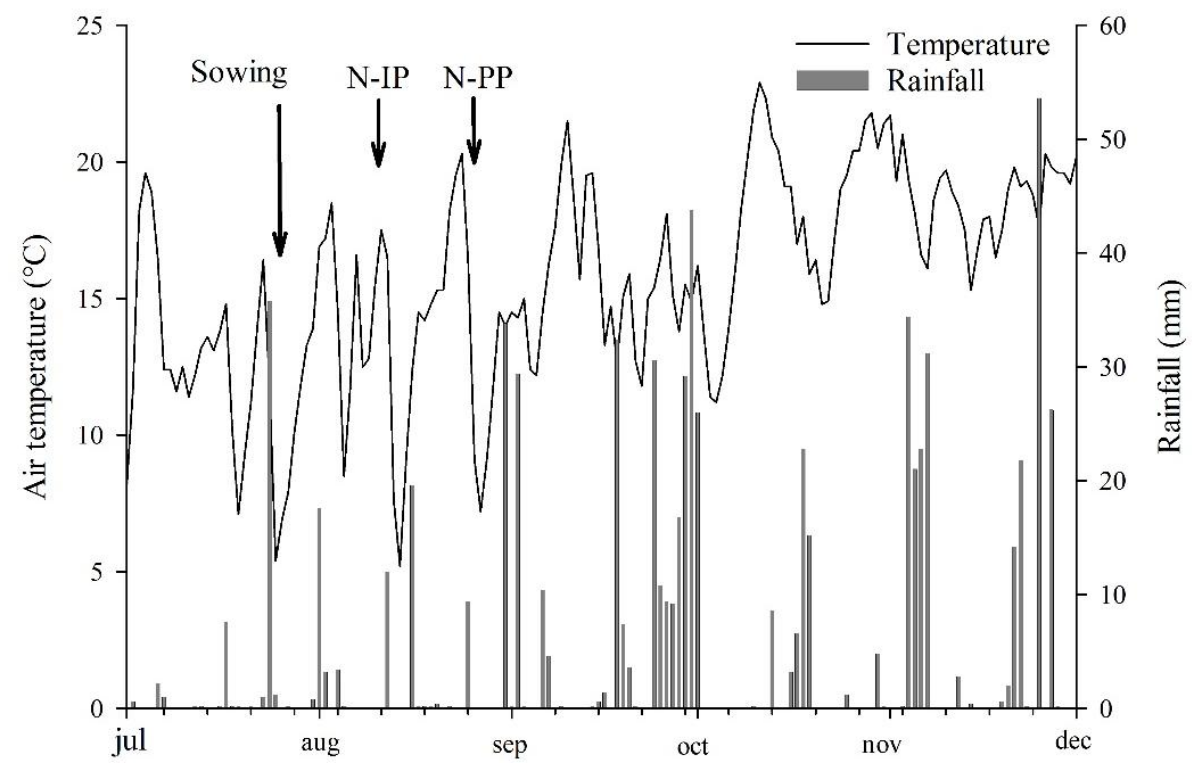

FIGURE 1 - Mean air temperature and daily rainfall during the experiment period in 2014. The arrows indicate the date of sowing, nitrogen fertilization at the beginning of tillering (N-IP) and nitrogen fertilization at full tillering (N-PP).

In the period prior to the implementation of the experiment, the area was cultivated under no-tillage system for 4 years, with the black oats/maize rotation. The chemical characterization of the soil in the $0.0-0.20 \mathrm{~m}$ layer presented the following results: $\mathrm{pH}_{(\mathrm{CaCl} 2)}=6.6$;
$53,61 \mathrm{~g} \mathrm{dm}^{-3}$ of $\mathrm{MO} ; 10.7 \mathrm{mg} \mathrm{dm}^{-3}$ of $\mathrm{P}_{\text {(Mehlich-1); }}$; $0.13 \mathrm{cmol}_{\mathrm{c}} \mathrm{dm}^{-3}$ of $\mathrm{K}^{+}{ }_{\text {(Mehlich-1); }} 7.98 \mathrm{cmol}_{\mathrm{c}} \mathrm{dm}^{-3}$ of $\left.\mathrm{Ca}^{2+}{ }_{(\mathrm{KCl}} 1.0 \mathrm{M}\right) ; 3.91 \mathrm{cmol}_{\mathrm{c}} \mathrm{dm}^{-3}$ of $\left.\mathrm{Mg}^{2+}{ }_{(\mathrm{KCl}} 1.0 \mathrm{M}\right)$; $0 \mathrm{cmol}_{\mathrm{c}} \mathrm{dm}^{-3}$ of $\left.\mathrm{Al}_{(\mathrm{KCl}} 1.0 \mathrm{M}\right)$; and effective CTC of $12.02 \mathrm{cmol}_{\mathrm{c}} \mathrm{dm}^{-3}$. 
The experimental design was randomized blocks, in a $3 \times 2$ factorial scheme, namely: three mineral sources of $\mathrm{N}$ (urea with $45 \% \mathrm{~N}$; nitrate with $30 \% \mathrm{~N}$; urea with NBPT urease inhibitor with $45 \% \mathrm{~N}$ ), combined with two application times: i) splitting the $\mathrm{N}$ dose in two periods: beginning of tillering (IP) and full tillering (PP) and ii) full application of $\mathrm{N}$ in crop $\mathrm{PP}$, totaling $100 \mathrm{~kg} \mathrm{ha}^{-1}$ of $\mathrm{N}$ in all the treatments. $50+50 \mathrm{~kg} \mathrm{ha}^{-1}$ of $\mathrm{N}$ were applied for the splitting, at the beginning of tillering and at full tillering.

Barley was sown on July $25^{\text {th }}, 2014$. The cultivar used was BRS Elis, characterized by being an early cycle cultivar, resistant to lodging and with high productive potential. The density used was 290 seeds per $\mathrm{m}^{2}$, in spacing between lines of $17 \mathrm{~cm}$. The basic fertilization for phosphorus $(\mathrm{P})$ and potassium $(\mathrm{K})$ was carried out with $200 \mathrm{~kg} \mathrm{ha}^{-1}$ of the 00-20-20 formulate. The $\mathrm{N}$ corresponding to the application scheduled for the beginning of tillering was carried out on August $10^{\text {th }}$, while the application at full tillering occurred on August $25^{\text {th }}$. The crop-related treatments followed technical recommendations for barley farming, by means of regular monitoring.

The evaluations were divided in two stages. The first at the flowering stage, where the plant height (AP) morphological character was measured; and the second, in the physiological maturation stage, where the yield components were evaluated, namely: number of ears per $\mathrm{m}^{2}$ (NEM), length of the ear (CE), number of grains per ear (NGE) and the mass of a thousand grains (MMG). For $\mathrm{AP}$, ten representative plants were selected within each parcel, disregarding three border lines and $1 \mathrm{~m}$ between the beginning and the end of each experimental unit. The measurements were performed using a ruler.

The NEM variable was measured by the individual ear count in 2 linear meters, while CE and NGE were measured by selecting 15 ears, where CE was determined with a ruler, and NGE through the individual ear count of the grains per ear unit. MMG was calculated by counting 350 grains, which were weighed with a semianalytical scale and the results extrapolated to one thousand grains. Yield was determined by calculating the mass of grains harvested in the useful area and the grains from the evaluations of the yield components. The results were corrected for a moisture content of $13 \%$ and extrapolated to $\mathrm{kg}$ per hectare.

The data were submitted to the test of normality of the errors and homoscedasticity of the variances, in order to check the basic assumptions of variance analysis (Anova). Then, the results were subjected to Anova, with the effect of the interaction being tested $(p<0.05)$ and the means compared by the Tukey test $(p<0.05)$. The data obtained were subjected to Pearson's simple correlation analysis. Statistical analyses were performed using the Sisvar software, version 5.6 (FERREIRA, 2019).

\section{RESULTS AND DISCUSSION}

For $\mathrm{N}$ sources and application timing, no significant interaction or significant correlations $(p>0.05)$ were verified in the analyzed variables. The yield components showed mean values of 19.8 spikelets per ear, 11.8 grains per ear, ear length of $7.6 \mathrm{~cm}, 614$ ears per $\mathrm{m}^{2}$ and $327 \mathrm{~g}$ for a thousand grain mass (Table 1). The mean height of the plants was $63.7 \mathrm{~cm}$, which represents the dwarf size characterized by the holding company. However, it was below the mean height of $74 \mathrm{~cm}$, characteristic of the BRS Elis cultivar (MINELLA et al., 2009). There was no single effect of the application timing for barley yield; but the $\mathrm{N}$ source did have an effect (Figure 2).

TABLE 1 - Yield components of barley after application of nitrogen $(\mathrm{N})$ as top dressing, with different sources and application timing, where IP represents the beginning of tillering and PP, full tillering.

\begin{tabular}{|c|c|c|c|c|c|c|c|}
\hline $\mathrm{N}$ sources & Timing & $\begin{array}{c}\text { Spikelets per } \\
\text { ears }\end{array}$ & $\begin{array}{c}\text { Grains per } \\
\text { ear }\end{array}$ & Ear length $(\mathrm{cm})$ & $\begin{array}{l}\text { Height of the } \\
\text { plants }(\mathrm{cm})\end{array}$ & $\begin{array}{c}\text { Ears per } \\
\mathrm{m}^{2}\end{array}$ & $\begin{array}{l}\text { Mass of a } \\
\text { thousand } \\
\text { grains }(\mathrm{g})\end{array}$ \\
\hline \multirow{2}{*}{ Nitrate } & $\mathrm{N}-\mathrm{IP}+\mathrm{N}-\mathrm{PP}$ & $18.7^{\mathrm{ns}}$ & $10.8^{\mathrm{ns}}$ & $7.2^{\mathrm{ns}}$ & $62.5^{\mathrm{ns}}$ & $657^{\mathrm{ns}}$ & $320.3^{\mathrm{ns}}$ \\
\hline & N-PP & 19.8 & 11.6 & 7.9 & 65.3 & 550 & 326.5 \\
\hline \multirow{2}{*}{ Urea } & $\mathrm{N}-\mathrm{IP}+\mathrm{N}-\mathrm{PP}$ & 19.5 & 11.3 & 7.5 & 63.0 & 555 & 332.8 \\
\hline & N-PP & 19.4 & 11.8 & 7.4 & 63.1 & 543 & 339.0 \\
\hline \multirow{2}{*}{ Urea/NBPT } & $\mathrm{N}-\mathrm{IP}+\mathrm{N}-\mathrm{PP}$ & 19.6 & 13.2 & 7.5 & 64.8 & 654 & 310.8 \\
\hline & N-PP & 22.1 & 12.1 & 7.8 & 63.6 & 723 & 335.0 \\
\hline$\overline{\mathrm{CV}(\%)}$ & & 8.94 & 10.18 & 4.13 & 2.55 & 21.88 & 10.96 \\
\hline
\end{tabular}

${ }^{\mathrm{ns}}=$ not significant by the Tukey test $(p<0.05)$.

The high content of organic matter in the soil (MOS), combined with the other chemical characteristics of the soil, may have favored that no differences were found between the fertilization timing for the evaluated parameters. According to Wamser and Mundstock (2007), under high soil $\mathrm{N}$ supply, the phenological stages for $\mathrm{N}$ fertilization have less importance in grain yield. As before the implementation of the experiment, the chemical characterization of the area revealed MOS contents of
$53.6 \mathrm{~g} \mathrm{dm}^{-3}$, which is an attribute indicating high $\mathrm{N}$ availability, it is suggested that there was a contribution of mineralized $\mathrm{N}$ for crop development, hiding the effects of the treatments. If we consider an $\mathrm{N}$ mineralization rate of $3 \%$ per year, and based on the MOS contents of the area under study, we would have a release of $161 \mathrm{~kg} \mathrm{ha}^{-1}$ of $\mathrm{N}$ per year, which would be released gradually and part could be absorbed by the crops (SCHONINGER et al., 2018). 
Ruffing et al. (1980) observed that approximately $33 \mathrm{~kg} \mathrm{ha}^{-1}$ of $\mathrm{N}$ were absorbed by the barley from the soil organic N mineralization. Nyborg et al. (1999), after conducting a field study in 92 locations, reported that when the nitrate $\left(\mathrm{NO}_{3}^{-}\right)$levels in the soil $(0-60 \mathrm{~cm})$ were greater than $88 \mathrm{~kg} \mathrm{ha}^{-1}$, the application of mineral sources had no effect on crop yield. Nevertheless, Fontoura et al.
(2017), upon developing $\mathrm{N}$ recommendation system for barley in the Center-South region of the state of Paraná, observed that higher $\mathrm{N}$ doses are needed at low levels of MOS. These studies reveal the contribution of the organic and mineral $\mathrm{N}$ of the soil to partially and fully supply the demand for $\mathrm{N}$ by the plant.

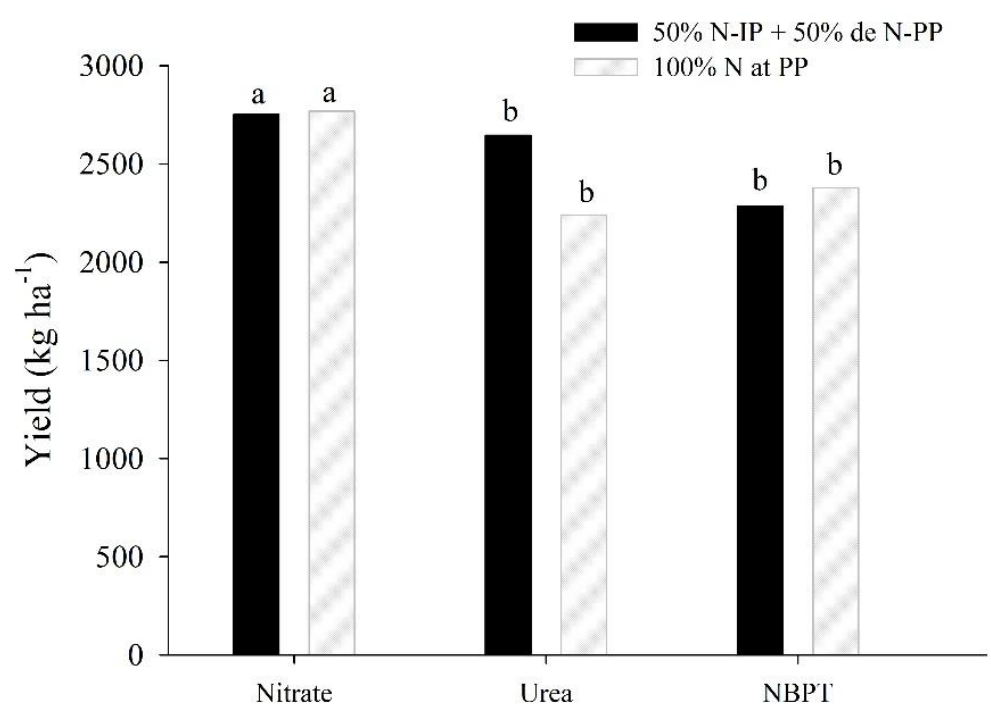

FIGURE 2 - Barley yield according to different nitrogen $(\mathrm{N})$ sources and application seasons, where N-IP represents application of $\mathrm{N}$ at the beginning of tillering and N-PP means application of $\mathrm{N}$ at full tillering of the crop. NBPT represents urea + urease inhibitor N-(n-butyl) thiophosphoric triamide. *Different letters within each season and for each source indicate significant differences between the $\mathrm{N}$ sources, according to the Tukey test $(p<0.05)$.

Another factor that may have contributed to the lack of response to the application timing of $\mathrm{N}$ are the climatic conditions of the experiment, with low rainfall (Figure 1), combined with the clayey texture of the soil, since these factors reduce $\mathrm{N}$ losses by leaching. In the same climate and soil conditions as the present study, however, with maize crops, Ribeiro et al. (2018) observed that splitting nitrogen fertilization, with $2 / 3$ of the dose applied before sowing, associated with the subsequent application of fertilizer at the time of sowing, tends to be viable only in drought conditions. According to SBCS/NEPAR (2019) in crops under a no-tillage system and low probability of $\mathrm{N}$ losses by leaching, nitrogen fertilization as topdressing in barley can be performed from pre-sowing to tillering.

Nitrogen supply via nitrate resulted in the highest yield values $(p<0.05)$, and its use promoted a $16 \%$ increase in yield in relation to the amidic forms of $\mathrm{N}$ (Figure 2). In a study by Malhi et al. (1988) in a greenhouse, barley plants also produced more when fertilized with $\mathrm{N}_{-} \mathrm{NO}_{3}{ }^{-}$compared to $\mathrm{N}-\mathrm{NH}_{4}{ }^{+}$, with this effect being enhanced when the $\mathrm{pH}$ of the soil was below 6.0. The same authors observed a reduction in $\mathrm{pH}$ due to ammonium and attributed the results obtained to the acidification caused by the ammoniacal source. When absorbing $\mathrm{NH}_{4}{ }^{+}$, protons are released and a consequent acidification of the rhizospheric soil takes place; when absorbing $\mathrm{NO}_{3}{ }^{-}$, the plant removes protons from the solution. This phenomenon occurs due to the maintenance of the cytoplasm internal electrical neutrality (PRADO, 2008).

These changes in the rhizospheric environment due to the $\mathrm{N}$ form can cause changes in the level of acidity, availability of nutrients, and it can consequently influence root development and yield of the crop. Furthermore, it is necessary to point out that the $\mathrm{N}$ absorbed in the form of $\mathrm{NO}_{3}{ }^{-}$can be stored in the vacuole or metabolized, while the $\mathrm{N}$ absorbed as $\mathrm{NH}_{4}{ }^{+}$must be completely metabolized, not being accumulated by the plant because it is toxic in high concentrations (PRADO, 2008).

Although the plant absorbs ammonium and nitrate, absorption in the nitric form is predominant; and this helps to explain the greater efficiency of this source in raising barley yield (Figure 2). In addition, nitrate is the most abundant form of $\mathrm{N}$ in the soil, due to the conditions of good drainage and aeration that favor the nitrification processes (SOARES et al., 2016). Another reasonable reason for the higher yield of barley with the use of a nitric source can be due to the lower N loss of the soil system. Amidic sources are subjected to losses due to ammonia volatilization when applied in the soil surface in no-tilage system, being enhanced in certain environmental conditions; resulting in losses of up to $43 \%$ of the applied $\mathrm{N}$ (MINATO et al., 2019), so that using the nitric source may have favored greater $\mathrm{N}$ availability for the crop. Thus, the conditions of low soil moisture during the 
experimental period may have favored the $\mathrm{N}$ losses by volatilization, even if small, or even reduced the nitrification rates.

On the other hand, the occurrence of $\mathrm{NO}_{3}$ leaching can also reduce the efficiency of fertilization, a fact that possibly did not occur in this study, since there were low rainfall in the days close to nitrogen fertilization (Figure 1). The $\mathrm{NO}_{3}^{-}$losses due to leaching are more accentuated in conditions of high rainfall and in sandy soils, since water is the main carrier for the $\mathrm{NO}_{3}{ }^{-}$ion be leached to deep layers, distant from the root system (THORUP-KRISTENSEN et al., 2009), a situation different from the one found in this study.

Using the NBPT urease inhibitor did not have advantages over conventional urea. Under the same experimental conditions, also in barley cropping, Ribeiro et al. (2020) observed the efficiency of NBPT in delaying the hydrolysis of urea in the first 6 days after fertilization; however, after this period, the release of $\mathrm{NH}_{4}{ }^{+}$and $\mathrm{NO}_{3}{ }^{-}$by this source was similar to conventional urea, which resulted in similar losses by $\mathrm{NH}_{3}$. However, the authors verified that NBPT is efficient in reducing the emission of nitrous oxide $\left(\mathrm{N}_{2} \mathrm{O}\right)$ in high moisture conditions of the soil. In a review by Cantarella et al. (2018), it was observed that the yield gain through the use of NBPT is in the order of $6.0 \%$, which can vary from -0.8 to $10.2 \%$, depending on the cultivated species.

According to Cantarella et al. (2018), although the acceptance of farmers for fertilizers containing urease inhibitors is growing, some limitations, such as the short period of effective inhibition and limited useful life, must be addressed by the research. The authors point out that, although urease inhibitors significantly reduce $\mathrm{NH}_{3}$ volatilization losses, they do not completely eliminate them. In situations where the potential losses are high, the use of urea applied in the soil surface, even with urease inhibitors, can result in considerable $\mathrm{N}$ losses, without showing higher efficiency than conventional urea in crop yield. The yield of $2,510 \mathrm{~kg} \mathrm{ha}^{-1}$ obtained in the experiment was close to the mean yield of $2,606 \mathrm{~kg} \mathrm{ha}^{-1}$ obtained in the 2014 crop-season for the southern region (CONAB, 2015). Thus, only with the use of fertilizer in the nitric form $\left(2,759 \mathrm{~kg} \mathrm{ha}^{-1}\right)$ was it possible to surpass the yield obtained in the Brazilian southern region.

The efficiency of $\mathrm{N}$ fertilization as topdressing depends, among other factors, on the climatic conditions and on the type of soil, as well as on the ability of the plants to extract nutrients during growing (NEUMANN et al., 2009). Given the importance of barley as an income source in the cold season of the year, the adoption of strategies that optimize grain yield in highly efficient production systems are essential. It is suggested that future studies, in addition to yield, consider the effects of nitrogen fertilizers on the dynamics of $\mathrm{N}$ in the soil-plantatmosphere system considering $\mathrm{N}$ losses by leaching, ammonia volatilization and $\mathrm{N}_{2} \mathrm{O}$ emission, in addition to the $\mathrm{N}$ uptake by the crops. Although the use of the nitric source provides fewer losses due to ammonia volatilization, this form of $\mathrm{N}$ is more subjected to $\mathrm{N}$ losses by leaching and denitrification.

\section{CONCLUSIONS}

Under subtropical climate conditions, in a clayey soil with high organic matter contents, applying $\mathrm{N}$ with urease inhibitor (NBPT), was not efficient for increasing barley yield in relation to conventional urea.

Using $\mathrm{N}$ in the nitric form yielded a $16 \%$ increase in barley yield in comparison to the amidic forms of nitrogen.

Splitting nitrogen fertilization did not presented advantages in relation to single application, regardless of the source used.

\section{REFERENCES}

ALLEY, M.M.; PRIDGEN, T.H.; BRANN, D.E.; HAMMONS, J. L.; MULFORD, R. L. Nitrogen fertilization of winter barley: principles and recommendations. Blacksburg: Virginia Cooperative Extension, 2019. Available at: https://www.pubs.ext.vt.edu/424/424-801/424-801.html. Accessed on: 14 Jan. 2020.

ALVARES, C.A.; STAPE, J.L.; SENTELHAS, P.C.; GONÇALVES, J.L.M.; SPAROVEK, G. Köppen's climate classification map for Brazil. Meteorologische Zeitschrift, v.22, n.6, p.711-728, 2013.

CANTARELLA, H.; OTTO, R.; SOARES, J.R.; SILVA, A.G.B. Agronomic efficiency of NBPT as a urease inhibitor: a review. Journal of Advanced Research, v.13, p.19-27, 2018.

CONAB. COMPANHIA NACIONAL DE ABASTECIMENTO. Acompanhamento da safra brasileira de grãos. Safra 2019/20. v.7, n.4, 2020. Available at: https://www.conab.gov.br/infoagro/safras/graos/boletim-da-safra-de-graos. Accessed on: 28 Jan. 2020.

CONAB. COMPANHIA NACIONAL DE ABASTECIMENTO. Acompanhamento da safra brasileira de grãos. Safra 2014/15. v.2, n.11, 2015. Available at: https://www.conab.gov.br/infoagro/safras/graos/boletim-da-safra-de-graos. Accessed on: 11 Jan. 2020.

FERREIRA, D.F. Sisvar: a computer analysis system to fixed effects split plot type designs. Revista Brasileira de Biometria, v.37, n.4, p. 529-535, 2019.

FONTOURA, S.M.V.; VIERO, F.; MORAES, R.P.; BAYER, C. Nitrogen fertilization of no-tillage winter cereals in the South-Central region of Paraná, Brazil. Revista Brasileira de Ciência do Solo, v.41, e0170009, 2017.

FORRESTAL, P.J.; HARTY, M.; CAROLAN, R.; LANIGAN, G.J.; WATSON, C.J.; LAUGHLIN, R.J.; MCNEILL, G.; CHAMBERS, B.J.; RICHARDS, K.G. Ammonia emissions from urea, stabilized urea and calcium ammonium nitrate: insights into loss abatement in temperate grassland. Soil Use and Management, v.32, [s.n.], p.92-100, 2016. 
MALAVOLTA, E.; VITTI, G.C.; OLIVEIRA, S.A. Avaliação do estado nutricional das plantas princípios e aplicação. 2a. ed. Piracicaba: POTAFOS, 1997. 319p. MALHI, S.S.; NYBORG, M.; CALDWELL, C.D.; HOYT, P.B.; LEITCH, R.H. Effect of ammonium and nitrate on growth and yield of barley on acid soils. Communications in Soil Science and Plant Analysis, v.19, n.7-12, p.1049-1063, 1988.

MINELLA, E.; ANTONIAZZI, N.; BOROWSKI, D.Z.; MOREIRA, M.I.P.; COSTAMILLAN, L.M.; EICHELBERGER, E.; NASCIMENTO JUNIOR, A.; CHAVES, M.S.; BRAMMER, S. Cultivar de cevada BRS Elis. Available at: $<$ https://ainfo.cnptia.embrapa.br/digital/bitstream/item/128 351/1/ID40974-2009-reuniaocevadaCD210.pdf>.

Accessed: 05 Jan. 2020.

MINATO, E.A.; BESEN, M.R.; CASSIM, B.M.A.R.; MAZZI, F.L.; INOUE, T.T.; BATISTA, M.A. Modeling of nitrogen losses through ammonia volatilization in second-season corn. Communications in Soil Science and Plant Analysis, v.50, n.1, p.2733-2741, 2019.

MUURINEN, S.; SLAFER, G. A.; PELTONEN-SAINIO, P. Breeding effects on nitrogen use efficiency of spring cereals under northern conditions. Crop Science, v.46, n.1, p.561-568, 2006.

NEUMANN, M.; OLIVEIRA, M.R.; SPADA, C. A.; FIGUEIRA, D. N.; POCZYNEK, M. Componentes de rendimentos e produção da planta de cevada em função de níveis de adubação nitrogenada em cobertura. Pesquisa Aplicada \& Agrotecnologia, v.2. n.3, p.61-68, 2009.

NYBORG, M.; MALHI, S.S.; MUMEY, G.; KRYZANOWSKI, L.; PENNY, D.C.; LAVERTY, D.H. Economics of nitrogen fertilization of barley and rapeseed as influenced by nitrate-nitrogen level in soil. Communications in Soil Science and Plant Analysis, v.30, n.5-6, p.589-598, 1999.

PRADO, R.M. Nutrição de plantas. 1a. ed. São Paulo: Editora Unesp, 2008. 407p.

RIBEIRO, R.H.; BESEN, M.R.; FIOREZE, S.L.; PIVA, J.T. Management of nitrogen fertilization in maize cultivated in succession to black oats in a temperate climate. Comunicata Scientiae, v.9, n.2, p.202-210, 2018. RIBEIRO, R.H.; BESEN, M.R.; SIMON, P.L.; BAYER, C.; PIVA, J.T. Enhanced-efficiency nitrogen fertilizers reduce winter losses of nitrous oxide, but not of ammonia, from no-till soil in a subtropical agroecosystem. Soil Use and Management, v,36, n.3, p.420-428, 2020.

RUFFING, J.; WESTERMANN, D.T.; JENSEN, M.E. Nitrogen management for malting barley. Communications in Soil Science and Plant Analysis, v.11, n.9, p.889-894, 1980.

SANTOS, H.G.; JACOMINE, P.K.T.; ANJOS, L.H.C.; OLIVEIRA, V.A.; LUMBRERAS, J.F.; COELHO, M.R.; ALMEIDA, J.A.; CUNHA, T.J.F.; OLIVEIRA, J.B. Sistema Brasileiro de Classificação de Solo. 3a. ed. Brasília: Embrapa, 2013. 353p.
SCHONINGER, E.L.; VILLALBA, H.A.G.; BENDASSOLLI, J.A.; TRIVELIN, P.C.O. Corn grain yield and $15 \mathrm{~N}$-fertilizer recovery as a function of urea sidedress timing. Anais da Academia Brasileira de Ciências, v.90, n.4, p.3299-3312, 2018.

SEAPDR. SECRETARIA DE ESTADO DA AGRICULTURA, DA PESCA E DO DESENVOLVIMENTO RURAL. 2019. Santa Catarina quer estimular a produção de cereais de inverno para alimentação animal. Available at: http://www.agricultura.sc.gov.br/index.php/noticias/938santa-catarina-quer-estimular-a-producao-de-cereais-deinverno-para-alimentacao-animal. Accessed: 05 Jan. 2020. SOARES, J.R.; CASSMAN, N.A.; KIELAK, A.M.; PIJL, A.; CARMO, J.B.; LOURENÇO, K.S.; LAANBROEK, H.J.; CANTARELLA, H.; KURUMAE, E.E. Nitrous oxide emission related to ammonia-oxidizing bacteria and mitigation options from $\mathrm{N}$ fertilization in a tropical soil. Scientific Reports, v.6, [s.n.], p.1-11, 2016.

SBCS/NEPAR. SOCIEDADE BRASILEIRA DE CIÊNCIA DO SOLO. NÚCLEO ESTADUAL DO PARANÁ. Manual de adubação e calagem para o estado do Paraná. Curitiba: SBCS/NEPAR, 2019. 289p.

THORUP-KRISTENSEN, K.; CORTASA, M.S.; LOGES, $\mathrm{R}$. Winter wheat roots grow twice as deep as spring wheat roots, is this important for $\mathrm{N}$ uptake and $\mathrm{N}$ leaching losses? Plant and Soil, v.322, n.1-2, p.101-114, 2009.

WAMSER, A.F.; MUNDSTOCK, C.M. Adubação nitrogenada em estádios fenológicos em cevada, cultivar “MN 698”. Ciência Rural, v.37, n.4, p.942-948, 2007. 